\title{
Assessment role of phagocytic neutrophil cells among different Wagner's grades of diabetic foot ulcers infections
}

Eidha Ali Bin-Hameed ( $\nabla$ eidha6@gmail.com )

Hadhramout University

Maryam Hamed Baras

Hadhramout University

\section{Research article}

Keywords: Phagocytic cells, Bacterial infection, Wagner's grades classification, Diabetic foot ulcers

Posted Date: July 27th, 2020

DOI: https://doi.org/10.21203/rs.3.rs-43537/v1

License: @ (i) This work is licensed under a Creative Commons Attribution 4.0 International License.

Read Full License 


\title{
Assessment role of phagocytic neutrophil cells among different Wagner's grades of diabetic foot ulcers infections
}

\section{Author details}

1. Eidha Ali Bin-Hameed

Associated professor of medical microbiology, Department of Biology, Faculty of Science, Hadhramout University, Yemen. Tel.0096773568330, E-mail: eidha6@ gmail.com

2. Maryam Hamed Baras

MSc of zoology, Department of Biology, Faculty of Science, Hadhramout University, Yemen. Tel. 0096702041514, E-mail: yaam8y@gmail.com

Corresponding author: Dr. Eidha Ali Bin-Hameed, Biology Department, Faculty of Sciences, Hadhramout University, Yemen, Tel.0096773568330, E-mail: eidha6@ gmail.com

\begin{abstract}
Background: Foot ulcers complications in diabetes mellitus (DM) patients are one of the significant medical problems and an economic burden. The aim of this study is to assessment role of phagocytic neutrophil cells and its relationship with the incidence of diabetic foot ulcers (DFU) infection of diabetic patients. A total of 60 venipuncture blood samples collected from diabetes mellitus, diabetic foot ulcer patients and healthy persons as control group. 20 swabs from the DFU patients were collected and processed for culture and susceptibility test after the ulcers classified according to Wagner's grades system. Phagocytic cells activity test was performed to determine the efficiency of phagocytic neutrophil cells in diabetic patients.
\end{abstract}

Results: Gram positive bacteria were the most prevalent in the DFU patients $57.1 \%$ with statistical significant relationship between the type of bacteria and grades of Wagner's classification followed by Gram negative bacteria in high grades of ulcers. Wagner's ulcers grade 1 and 2 were the most prevalence in DFU patients 30\%. There was a weak negative correlation between the efficiency of phagocytic neutrophil cells activity and grade ulcers classified $(\mathrm{r}=-0.323)$. Amikacin and ciprofloxacin were the most effective antibiotics against $90.5 \%$ and $81 \%$ of the bacterial isolates respectively, whereas ampicillin, cefepime and cefadroxil were less effective antibiotics against the bacterial isolates.

Conclusion: When the grade of ulcer increased, the bacterial resistance to antibiotics increased, and this was emphasis the correlation with prevalent of Gram negative bacteria in the high grade of 
ulcers with high resistance of antibiotics. In contrast, the grade of ulcer increased, the efficiency of phagocytic neutrophil cells decreased.

Key words: Phagocytic cells, Bacterial infection, Wagner's grades classification, Diabetic foot ulcers.

\section{Background}

Diabetes mellitus (DM) is one of the main global health problems. It's defined as a metabolic disorder resulting from a defect in insulin secretion, insulin action, or both, which leads to chronic hyperglycemia [1]. Several polymorphonuclear leukocyte cells (PMNLs) affected by hyperglycemia, neutrophil's functions impair occur in diabetic subjects including impaired migration, phagocytosis, intracellular killing and chemotaxis, which may be due to decreased PMNLs membrane fluidity [2]. There is clinical evidence pointing to the higher prevalence of infectious diseases among individuals with DM [3]. Foot ulcers remain one of the most distressing complications of a diabetic patient and it's one of the most significant and devastating complications of diabetes [4]. Wagner's ulcer grades classification is one of the most widely used and universally accepted grading systems for diabetic foot ulcers (DFU), consisting of six simplistic wound grades used to assess ulcer depth as following: grade-0; high risk foot and no ulceration, grade-1; superficial ulceration, grade-2; deep ulcer - cellulitis, grade-3; osteomyelitis with ulceration or abscess, grade-4; gangrenous patches and grade-5; gangrene of entire foot [5].

Phagocytic cells activity is affected by blood sugar levels, and the infection of lesions grades of DFU also affected by phagocytic activity of neutrophil cells. This study aimed to assessment role of phagocytic neutrophil cells and its role to fight the bacterial infection of diabetic foot ulcers classified according to Wagner's grades system, as well as to determine the antibiogram patterns of bacterial isolated from diabetic foot ulcers.

\section{Results}

\section{Diabetic foot ulcers classification}

As an assessment of grades of DFU as described by Wagner's classification system at the time of study period, the results showed that grade I and II seen in 6(30\%), grade III $5(25 \%)$, grade IV 1(5\%) and grade V 2(10\%), table (1). 
Table (1): Distribution of diabetic foot ulcers according to Wagner's classification

\begin{tabular}{ccc}
\hline \multirow{2}{*}{ Ulcer grade } & \multicolumn{2}{c}{ DFU } \\
\cline { 2 - 3 } & No. & $\%$ \\
\hline Grade I & 6 & 30.0 \\
\hline Grade II & 6 & 30.0 \\
\hline Grade III & 5 & 25.0 \\
\hline Grade IV & 1 & 5.0 \\
\hline Grade V & 2 & 10.0 \\
\hline Total & 20 & 100.0 \\
\hline
\end{tabular}

\section{Distribution of bacterial isolated}

Twenty one bacterial species were isolated from DFU according to the conventional methods for identification of bacteria. Gram positive bacteria isolates were S. aureus 3(14\%), Staphylococcus epidermidis (S. epidermidis) 3(14\%), Streptococci species 3(14\%), Staphylococcus saprophyticus (S. saprophyticus) 2(10\%) and methicillin resistance Staphylococcus aureus (MRSA) 1(5\%). Other isolates of Gram negative were Proteus mirabilis (P. mirabilis) 2(9\%), Morganella morganii (M. morganii) 2(9\%), Pseudomonas aeruginosa (P. aeruginosa) 1(5\%), Serratia species 1(5\%), Escherichia coli (Esch. coli) 1(5\%), Klebsiella species 1(5\%) and Citrobacter freundii (C. freundii) $1(5 \%)$.

\section{Bacterial species of DFU associated with Wagner's grades system}

As shown in table (2), the superficial ulcer grades infections were caused by Gram positive bacteria, while Gram-negative bacteria showed predominant in deep ulcer grades infections with statistically significant association (P-value 0.057). The distribution of different bacterial species isolated from DFU cases according to Wagner's grades classification given in figure (1).

Table (2): Distribution of bacterial isolated according to Wagner's grades of ulcers

\begin{tabular}{|c|c|c|c|c|c|c|}
\hline \multirow{2}{*}{ Bacterial groups } & \multicolumn{5}{|c|}{ Wagner's ulcer grades } & \multirow{2}{*}{ P-value } \\
\hline & Grade I & Grade II & Grade III & Grade IV & Grade V & \\
\hline Gram positive bacteria & $9.6 \%$ & $33.5 \%$ & $9.6 \%$ & $4.8 \%$ & - & \multirow{2}{*}{$0.057 *$} \\
\hline Gram negative bacteria & $14.4 \%$ & - & $14.4 \%$ & $4.8 \%$ & $9.6 \%$ & \\
\hline
\end{tabular}




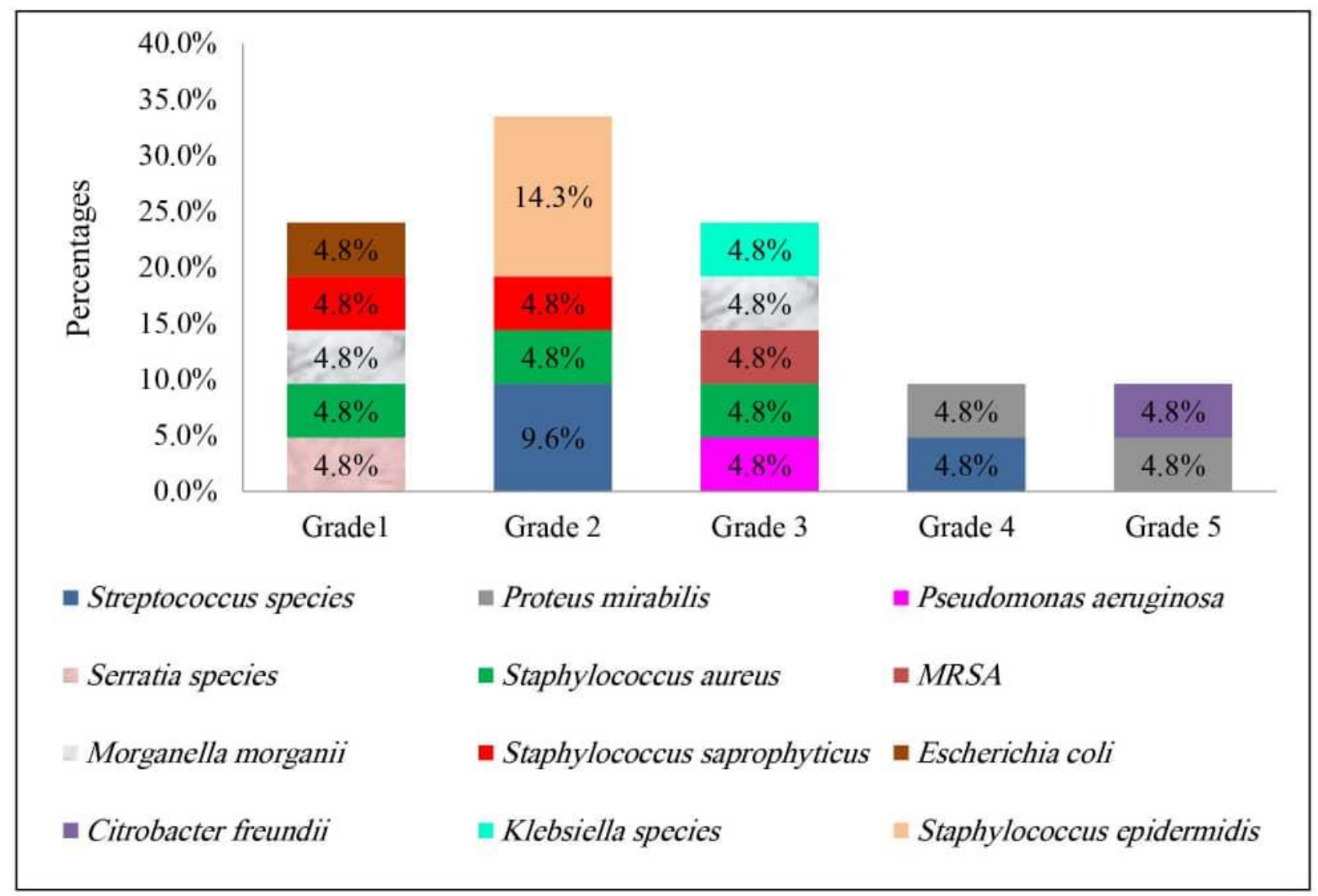

Figure (1): Bacterial species of DFU according to Wagner's ulcers grades classification

\section{Antibiotics resistance patterns of bacterial isolates}

In this study, Staphylococci species were resistant for ampicillin $100 \%$ and high sensitive to ciprofloxacin, amikacin, trimethoprim and cefaclor 100\%. MRSA showed high resistant to cefixime, ampicillin, cefadroxil and trimethoprim antibiotics $100 \%$ and high sensitive for vancomycin, amikacin, ciprofloxacin, amoxyclav and cefepime 100\%. Streptococci species were resistant for cefepime, cefixime, ampicillin, cefadroxil and cefaclor 100\%, and sensitive for ciprofloxacin and amikacin $100 \%$.

Gram negative bacteria showed high resistance to ampicillin and cefixime $88.8 \%$ followed by cefadroxil, cefaclor, cefepime $77.8 \%$ and trimethoprim $55.6 \%$. Most of the isolates were susceptible to amikacin $77.8 \%$ and ciprofloxacin $55.6 \%$, table (3). 
Table (3): Antibiotics sensitive, intermediate sensitive and resistance patterns of bacterial isolates

\begin{tabular}{ccccccccccc}
\hline \multirow{2}{*}{ Patterns } & \multicolumn{10}{c}{ Antibiotics discs } \\
\cline { 2 - 11 } & CIP & AMC & CPM & AK & CFM & AMP & CF & TR & CFR & VA \\
\hline S No.(\%) & $17(81.0)$ & $12(61.9)$ & $10(47.6)$ & $19(90.4)$ & $2(9.5)$ & $0(0.0)$ & $11(52.4)$ & $11(52.4)$ & $9(42.9)$ & $10(83.3)$ \\
\hline I No.(\%) & $0(0.0)$ & $1(4.8)$ & $1(4.8)$ & $1(4.8)$ & $0(0.0)$ & $1(4.8)$ & $0(0.0)$ & $4(19.0)$ & $1(4.8)$ & $0(0.0)$ \\
\hline R No.(\%) & $4(19.0)$ & $8(33.3)$ & $10(47.6)$ & $1(4.8)$ & $19(90.5)$ & $20(95.2)$ & $10(47.6)$ & $6(28.6)$ & $11(52.4)$ & $2(16.7)$ \\
\hline
\end{tabular}

\section{Antibiotics resistance patterns associated with Wagner's ulcers grades}

There was an increased resistance of bacterial isolates with increased grades of Wagner's classification as shown in figure (2). According to Pearson correlation test there was statistically significant correlation $(\mathrm{P}$-value $=0.05 ; \mathrm{r}=0.369)$.

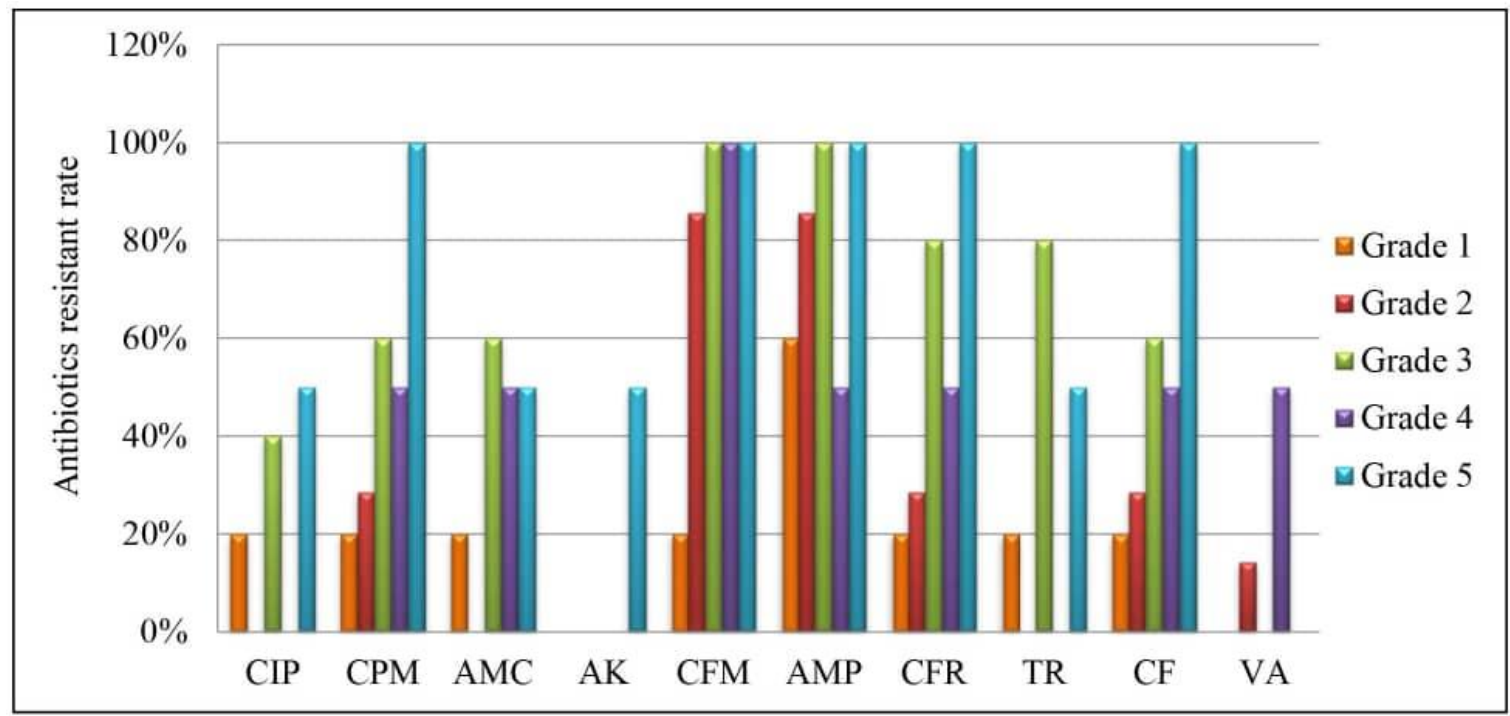

Figure (2): Antibiotics resistance patterns of bacterial isolated in different Wagner's grades

\section{Phagocytic neutrophil cells activity test}

According to phagocytic cells activity test, DM and DFU patients had no high efficient phagocytic neutrophil activity, 1 and 0 respectively as given in table (4). 
Table (4): Phagocytic neutrophil cells activity among studied groups

\begin{tabular}{ccccc}
\hline \multirow{2}{*}{ Group } & \multicolumn{4}{c}{ Phagocytic neutrophil cells activity } \\
\cline { 2 - 5 } & Low & Medium & High & Total \\
\hline Control & 0 & 10 & 10 & 20 \\
\hline DM & 2 & 17 & 1 & 20 \\
\hline DFU & 6 & 14 & 0 & 20 \\
\hline Total & 8 & 41 & 11 & 60 \\
\hline
\end{tabular}

The mean of phagocytosis was completely different between the three groups studied (control, DM and DFU patients) using LSD with high significant difference statistics as shown in table (5).

Table (5): The mean of phagocytic neutrophil cells activity among studied groups

\begin{tabular}{cccc}
\hline \multirow{2}{*}{ Group } & \multicolumn{3}{c}{ Mean \% } \\
\cline { 2 - 4 } & Control (71.35\%) & DM (52.70\%) & DFU (43.05\%) \\
\hline Control & - & $0.000^{*}$ & $0.000^{*}$ \\
\hline DM & $0.000^{*}$ & - & $0.001^{*}$ \\
\hline DFU & $0.000^{*}$ & $0.001^{*}$ & - \\
\hline
\end{tabular}

*Statistical significant at $\mathrm{P}$-value $<0.05$

In this study we correlated the degree of wounds with phagocytic efficiency to understand the development of the ulcer grade and role of neutrophil phagocytic cells. Statistically, there was low insignificant correlation between these two variables as given in table (6) and figure (3).

Table (6): Correlation between phagocytic neutrophil cells activity and Wagner's grades of ulcer

\begin{tabular}{|c|c|c|c|}
\hline Variable & No. & P-value & Pearson correlation (r) \\
\hline Grades of ulcers & 20 & \multirow{2}{*}{0.164} & \multirow{2}{*}{-0.323} \\
\hline Phagocytosis & 20 & & \\
\hline
\end{tabular}




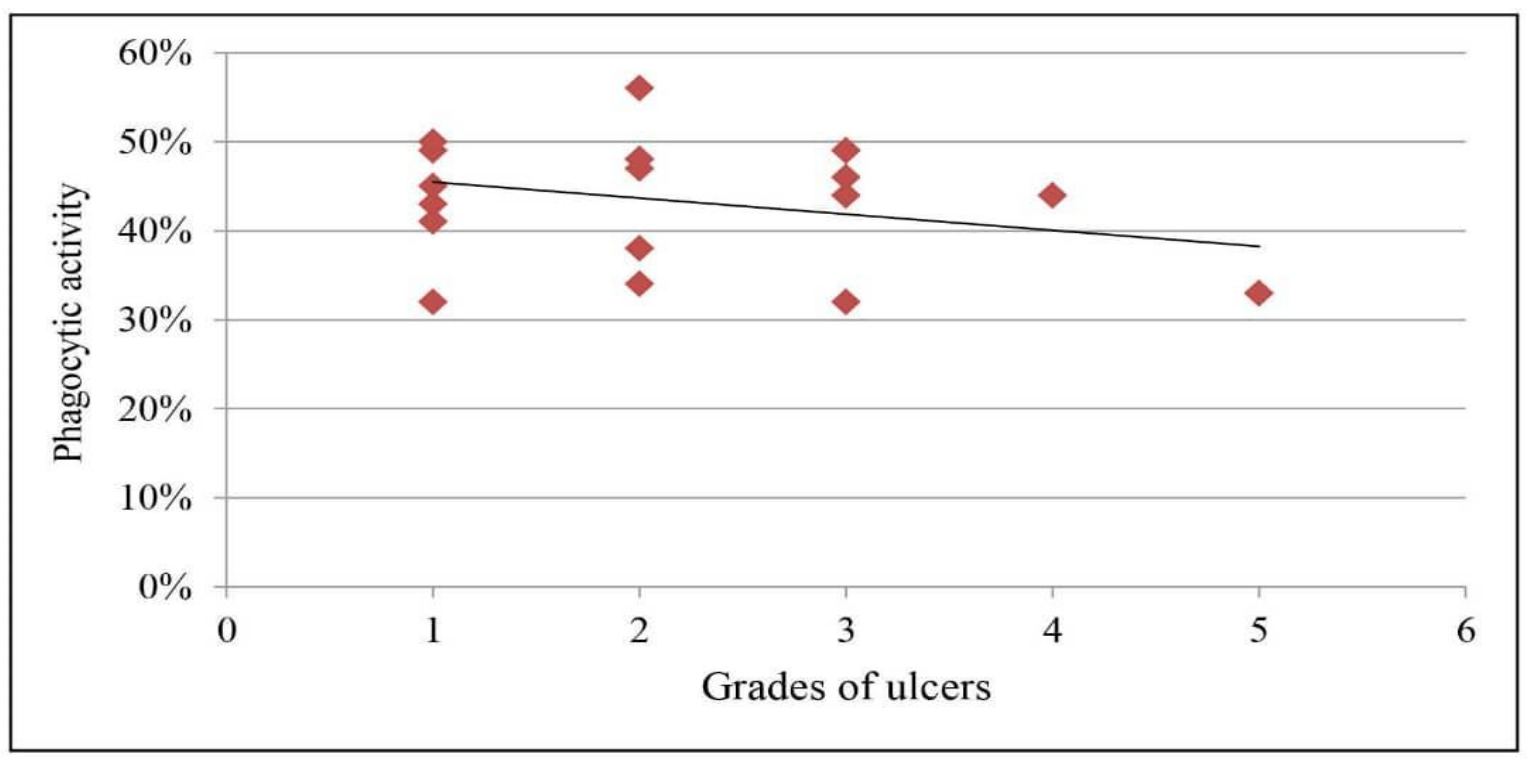

Figure (3): The correlation between phagocytic neutrophil cells activity and Wagner's grades of ulcers

\section{Discussion}

Identifying the risk factors of DFU might help to develop better prevention strategies in diabetic patients. In this study we attempted to find if there is a relationship between the phagocytic neutrophil cells activity and the Wagner's grades of the diabetic ulcers. Wagner's grade 1 and 2 ulcers classification were the most common prevalence $30 \%$ in ulcers of diabetic patients, and these results were compatible with other studies conducted in different countries [13-15], but disagree with a previous study reported that Wagner's grade 2 and 3 ulcers were the most common prevalence [16]. Grade 4 was the lowest prevalence in this study, and this contrast with other studies revealed that the grade 4 was the most common prevalence in DFU $[17,18]$. Other studies showed the grade 4 was commonly infected with mixed variety of bacteria including extended spectrum beta-lactamase (ESBL) Klebsiella species and MRSA [17], also, highly multiple bacterial infection were more incidence in DFU grade 4 [19]. Our study results found that multiple bacterial infections was associated with grade 2 and 4 of Wagner's ulcers classification, while other study revealed that non-significant difference of the mean number of isolates and diabetic deep tissue infection of different grades [20].

In this study, Gram positive bacteria showed an increased prevalence $57.1 \%$ in diabetic ulcers with similar results of different studies $77 \%$ [21], 35\% [22] and 51.1\% [5]. The most common bacterial isolates from diabetic ulcers in this study were Staphylococci species $40.8 \%$ compatible to other findings showed that Staphylococci species accounted 43.37\% [23], whereas Gram negative 
bacteria were the most frequently pathogenic agents reported in other studies 51\% [24], 56.1\% [25], $61 \%$ [26], $67 \%$ [27] and 51.2\% [28].

Interestingly, our study revealed high rate of $S$. aureus $14.3 \%, S$. epidermidis $14.3 \%, S$. saprophyticus $9.5 \%$ and MRSA $4.8 \%$. These results were compatible with the findings of other studies showed that S. aureus $19.4 \%$, S. epidermidis $18.4 \%$ and other Staphylococci species $3.6 \%$ [29], Other study showed the most commonly isolated S. aureus $30 \%$, followed by S. saprophyticus $19 \%$ and S. epidermidis $10 \%$ [30]. Another study showed that S. aureus 25\%, S. saprophyticus $15 \%$ and S. epidermidis $7 \%$ were the most isolated from DFU [14].

Streptococci species were the second most commonly isolated pathogens in our study $14.3 \%$, this is nearly with other studies isolated Streptococci species 17\% [31], 16\% [32] and 15.6\% [33]. Poor control of blood glucose was associated with a high relative abundant colonization by Staphylococci species and Streptococci species [34]. So, the most cases of DFU who have mixed infection of Staphylococci species and Streptococci species were poor glycemic control patients in our study.

P. mirabilis and M. morganii accounted $9.5 \%$ of predominant Gram negative bacteria in DFU in this study. High prevalence of Proteus species was reported in different studies [22, 30, 35], while M. morgani showed isolated low prevalence 3.16\% [36]. P. aeruginosa accounted $4.8 \%$ with resistance for the most antibiotics used in this study. Similar results found that Pseudomonas species were the most common isolated from DFU [5, 31, 32, 37-39]. P. aurginosa may cause an invasive form, sometimes in diabetics which fails to respond to topical antibiotic therapy [40]. Additionally, significant delay in wound healing cause of $P$. aeruginosa biofilms inhibit neutrophil movement [41]. So the coordinated control of the production of virulence and antibiotic resistance factors and the ability to adapt to various environmental changes is a likely and important reason that $P$. aeruginosa is a successful and common pathogen [42].

The prevalence of Klebsiella species and Esch. coli was $4.8 \%$ in this study, this agreed with other study results $4 \%$ [14], and disagreed with other study recorded a high rates of Klebsiella species $12.6 \%$ and Esch. coli $17.9 \%$ isolated from DFU [36]. Also, C. freundii and Serratia species isolates accounted $4.8 \%$ in this study, and is comparable with other results 5\% [22], 3.85\% [5], 4.3\% [43] for C. freundii and $2.3 \%$ for Serratia species [44]. Different geographical area could have contributed to different types of bacterial isolated [35].

The results of numerous studies conducted on the bacterial profiles of DFU showed a varied and often contradictory findings [39]. The reason for this difference in findings could be attributed to the difference in the causative agents, geographic variations or the severity of the infections [32]. 
In our study, the diabetic patients have superficial wounds of Wagner's grades classification I and II were mostly infected with Gram positive bacteria. Staphylococci and Streptococci species were the predominant pathogens, whereas Gram negative bacteria were more frequently isolated from Wagner's wounds classification grades III and V. These findings are in agreement with various studies concluded that an increasing of Wagner's grades, the proportion of bacterial infections were increased [2, 24, 35, 44, 45]. However, the percentage of S. aureus decreased with increased Wagner's grades similar findings reported in other study [24]. MRSA is an increasing problem in industrialized and developing countries. It is commonly believed to be an important cause of poor outcome, increased duration of hospital stay, increased cost and mortality [17, 46]. In this study, MRSA were associated with Wagner's grade 3 ulcer classification, and other study showed that Wagner's ulcers grade 3 were commonly infected with MRSA [17].

This study showed high level resistance of bacterial isolates to ampicillin 95\%, this ratio showed in other studies reported 92.4\% [44], 94.9\% [47, 48], and 50\% [35]. This increased of resistance may be attributed to the fact that ampicillin has been widely abused and frequently implicated in selfmedication [47]. Cefepime was active against $47.6 \%$ of isolates, this result agreed with other reports $41 \%$ [43], $61.9 \%$ [49], 42.4\% [32], $46.7 \%$ [50].

Our results revealed that amikacin was the most effective antibiotic against $90.5 \%$ of the bacterial isolates. This result was similar to that showed 75.4\% [51], 96.7\% [44], 82.9\% [52], 90\% [26], while it's less activity showed in other studies 54.7\% [51], 54.5\% [54], 62.7\% [45]. Also, ciprofloxacin showed greater susceptibility to the isolates $81 \%$, this result was approved with several studies reported sensitivity of ciprofloxacin was 63.7\% [55], 61.8\% [50], 78.8\% [33] and $77.3 \%$ [56], while other studies showed high resistant bacteria to ciprofloxacin $51.2 \%$ [57], 71.8\% [54].

In this study, vancomycin showed $83.3 \%$ sensitivity of Gram positive bacteria isolated. This similar to other studies $90.1 \%$ [55], 95\% [36], 98.2\% [24], while other study showed low sensitivity of vancomycin $44.5 \%$ [44]. However, other studies showed 100\% of Gram positive bacteria susceptible to vancomycin $[5,27,32,35,50,58]$.

Amoxyclav was active against bacterial isolated $61.9 \%$ in this study, and this result was in accordance with the studies showed sensitivity amoxyclav were 67.4\% [27], 49\% [55], 57.2\% [57]. In contrast, other studies showed high resistance amoxyclav 79\% [44], 81.8\% [54]. Cefexime showed low sensitivity $9.5 \%$ for the isolated bacteria in our study. Similar low rate reported in other study 3.2\% [59]. While the sensitivity for Gram negative bacteria to cefexime was 70.7\% [5], and for Gram positive bacteria was $77.3 \%$ [33]. The sensitivity of cefaclor was $47.6 \%$ of bacterial 
isolates in this study. This was compatible with the results of other study showed the second generation of cephalosporin was 50\% [44]. Other studies showed that cefaclor was active 58.4\% against Gram positive bacteria [54], and 92.8\% against Gram negative bacteria [35].

Trimethoprim had sensitivity $52.4 \%$ of bacterial isolates in this study. It's similar with the results of other studies $50 \%$ [44], 70.3\% [35], while the sensitivity to co-trimoxazole was low in other studies $16 \%$ [36], 14.3\% [56]. Cefadroxil was active 52.4\% against bacterial isolates. Other study indicated that first generation of cephalosporin was sensitive 41.7\% [43], 16.1\% [32]. Other studies showed the sensitivity of cefadroxil to Gram negative bacteria was $44.4 \%$ [50] and $11 \%$ [24].

Our study revealed that a low significant positive correlation between the antibiotics resistant and increasing of Wagner's grades classification. Such relation have previously reported that an increasing of Wagner's grades, the resistance rates to some antibiotics increased [60].

This study indicated a significant reduction in phagocytic activity in DM and DFU patients compared with control group. In addition, our baseline results confirm and extend previous reports concerning the impairment of phagocytosis that occurs in neutrophil cells from diabetic patients than non-diabetic patients [61]. Other studies showed a significant reduction in phagocytic cells activity in Type-1 DM and Type-2 DM [62,63]. This difference may be due to that hyperglycemia impairs granulocyte functions including adherence, chemotaxis, phagocytosis and bactericidal activity [64]. So, hyperglycemia reduced response of neutrophil function and disorders of humoral immunity as one of the long-term effects of elevated mean blood glucose (MBG) or HbA1c, also the impaired micro-vascular circulation in patients with diabetic foot limits the access of phagocytes favouring development of infection [3, 26, 65].

One of the strengths of our study results find the relationship between the manner of immune response involving phagocytic cells activity and the degree of wound. The study results showed a weak inverse correlation between the ratio of phagocytic cells activity and the degree of wound in Wagner's classification (P-value $0.164 ; \mathrm{r}=-0.323$ ). However, in our knowledge, there have been no reports in the literature regarding the correlation between phagocytic cells activity and the degree of wound in diabetic foot patients to support our result or to know the reasons of this relation we need further deep studies to be clarified.

\section{Conclusion}

When the grade of ulcer increased, the bacterial resistance to antibiotics increased, and this was emphasis the correlation with prevalent of Gram negative bacteria in the high grade of ulcers with high resistance of antibiotics. In contrast, the grade of ulcer increased, the efficiency of neutrophil 
phagocytic cells decreased. Further immunological and bacteriological investigations needed to control the increasing of antibiotics resistance in diabetic foot ulcers patients. We recommended when the grade of ulcer classified is high, a bacterial culture and sensitivity testing should be done to avoid complications of the increasing bacterial resistance to antibiotics.

\section{Methods}

\section{Study design and samples collection}

A case-control and analytical study was conducted during a period from November 2018 to May 2019 on diabetes mellitus and diabetic foot ulcer patients in different hospitals of Mukalla city Hadhramout / Yemen. A total of 60 volunteers were selected randomly and classified into 20 patients of DFU, 20 patients of DM and 20 healthy persons as control group. About 10ml of venipuncture blood were collected in ethylene diamine tetraacetic acid (EDTA) for phagocytic neutrophil activity test.

A sterile swabs were collected from ulcers after cleaned with sterile saline to remove accumulated drainage and transient skin flora. The swabs moistened with sterile saline if the wounds were dry. Then the swabs kept at room temperature and delivered to the microbiology laboratory for culture [6].

\section{Classification of diabetic ulcers}

The ulcers of diabetic foot patients were classified according to Wagner's grades classification system as an assessment of five grades at the time of study period.

\section{Phagocytic neutrophil cells activity test}

Phagocytic cells activity test was performed according to the methods described by [7-10] with minor modifications. In briefly, normal saline suspension of pathogenic strain Staphylococcus aureus (S. aureus) colonies was prepared and the visible turbidity was adjusted to 0.5 McFarland turbidity standard yielding an approximately $1.5 \times 10^{8} \mathrm{CFU} / \mathrm{ml}$. About $1 \mathrm{ml}$ of EDTA whole blood mixed with $1 \mathrm{ml}$ of saline bacterial suspension, then incubated for one hour at $37^{\circ} \mathrm{C}$. One drop of incubated mixture was placed on a slide of microscope to make a thin smear. The smear was lifted to dry for 3 minutes, and fixed with ethanol $96 \%$, then placed in hematoxylene stain for 10 minutes. After water washing, the smear placed in eosin stain for 30 seconds, then washed by water and examined under light microscope with 100x oil immersion. The total number of S. aureus ingested within 100 neutrophil cells were counted and divided by 100 to give the percentage of phagocytic cells activity. 


\section{Isolation and identification of bacterial pathogens}

All swab samples of ulcers were inoculated on the blood agar and MacConkey agar media (Oxoid/England). The culture plates were incubated under aerobic conditions at $37^{\circ} \mathrm{C}$ for 24 hours. After incubation, the growing of bacterial isolates were recognizable by colonies features. Identification of bacterial species was made based on reaction of Gram stain, morphology and biochemical characteristics using different available tests, catalase; coagulase; DNase; mannitol fermentation; urea; citrate; Kligler iron agar, sulphide indole motility and oxidase [11].

\section{Antibiotic susceptibility testing}

Antibiotic susceptibility testing was done using Kirby-Bauer disc diffusion method on Mueller Hinton agar (Oxoid/England) according to the standard guidelines of the Clinical Laboratory Standards Institute (CLSI) for testing ampicillin, cefepime, cefadroxil, ciprofloxacin, cefixime, cefaclor, trimethoprim, amoxyclav, methicillin, amikacin and vancomycin [12].

\section{Statistical analysis}

Data analyzed using the software of Statistical Package for Social Sciences (SPSS) version 25. The graphs presented using the software program (Excel for Windows Microsoft) version 10. Descriptive statistics (frequencies and percentages) for study variables were obtained and compared using least significant difference test (LSD) and one away ANOVA test. The association between different groups of the explanatory variables was measured and compared using Pearson Chi-square $(\chi 2)$ test. The relationship between the variables examined by the Pearson correlation (r) test. The level of significance was set at P-value less than 0.05 .

\section{Abbreviations}

DM: Diabetes mellitus, DFU: Diabetic foot ulcers, PMNLs: Polymorphonuclear leukocyte cells, CFU: Colony forming unit, EDTA: Ethylene diamine tetraacetic acid, CLSI: Clinical and Laboratory Standards Institute, SPSS: Statistical Package for Social Sciences, LSD: Least significant difference test, MRSA: Methicillin resistance Staphylococcus aureus, S: Sensitive, I: Intermediate sensitive, R: Resistance, CIP: Ciprofloxacin, CPM: Cefepime, AMC: Amoxiclav, AK: Amikacin, CFM: Cefixime, AMP: Ampicillin, CFR: Cefadroxil, TR: Trimethoprim, CF: Cefaclor, VA: Vancomycin.

\section{Acknowledgements}


Great thanks expressed to department of biology, faculty of science, Hadhramout university/Yemen for their efforts in developing scientific research.

\section{Authors' contributions}

All authors conceived, designed the experiments and wrote the manuscript. Maryam Hamed Baras analyzed the experimental results, performed the statistical analysis and interpreted all of the data. Eidha Ali Bin-Hameed reviewed and edited the manuscript. All authors read and approved the final manuscript.

\section{Funding}

Non funding

\section{Availability of data and materials}

All data generated or analysed during this study are included in this published article.

\section{Ethics approval and consent to participate}

Ethical approval for this study was obtained from Hadhramout University before commencing the study. The information were taken from the participants after they agreed to it verbally according to the informed consent with confidentiality of each participant as well as the results.

\section{Consent for publication}

Not applicable.

\section{Competing interests}

The authors declare that they have no competing of interests.

\section{References}

1. Aynalem SB, Zeleke AJ. Prevalence of Diabetes Mellitus and Its Risk Factors among Individuals Aged 15 Years and Above in Mizan-Aman Town, Southwest Ethiopia, 2016: A Cross Sectional Study. Int J Endocrinol. 2018; DOI: https://doi.org/10.1155/2018/9317987

2. Vasanthan K, Vengadakrishnan K, Surendran P. Clinical Profile of Diabetic Foot Infections. Int J Sci Study (IJSS). 2018; 6(1): 24-27.

3. Casqueiro J, Alves C. Infections in patients with diabetes mellitus: A review of pathogenesis. Indian J Endocrinol and Metab. 2012; 16(1): 27-36. 
4. Rosyid FN. Etiology, Pathophysiology, diagnosis and management of diabetic's foot ulcer. Int J Res Med Sci. 2017; 5(10): 4206-4213.

5. Malepati S, Vakamudi P, Kandati J, Satish S. Bacteriological study of diabetic foot ulcer according to Wagner's classification: a one-year study. Int Surg J. 2018; 5(1): 98-104.

6. Karmaker M, Sanyal SK, Sultana M, Hossain MA. Association of bacteria in diabetic and nondiabetic foot infection - An investigation in patients from Bangladesh. J Infect Public Health. 2016; 9: 267-277.

7. Shafik AO, Ibrahim RM, Awadalla GM, Amer GA, Moustafa MS. Bacterial and Immunological Study of Diabetic Foot. Egyp J Med Microbiol. 2011; 20(2): 1-8.

8. Alasady T, Hassan H, Mohsen W. Evaluation the phagocytosis activity in patients with type II diabetes mellitus. Kerbala J Pharma Sci. 2014; 7: 172-182.

9. Dewangan G, Hirpurkar S, Giri D, Kashyap D. Assessment of innate immunity by phagocytic activity in non-descript and Sahiwal cattle in Chhattisgarh. Veterinary World. 2014; 7(11): 943 947.

10. Shodja M, Knutsen R, Cao J, Oda K, Beeson L, Fraser G, Knutsen S. Effects of glycosylated hemoglobin levels on neutrophilic phagocytic functions. J Diabetes Endocrinol. 2017; 8(2): 916.

11. Tille PM. Bailey \& Scott's Diagnostic Microbiology. $13^{\text {st }}$ ed. China: Mosby, Inc., an affiliate of Elsevier Inc. 2014.

12. Clinical and Laboratory Standards Institute (CLSI). Performance standards for antimicrobial susceptibility testing. $2^{\text {th }}$ ed. CLSI supplement M100. Wayne, PA. CLSI. 2019.

13. Konar J, Das S. Bacteriological Profile of Diabetic Foot Ulcers, With a Special Reference to Antibiogram in a Tertiary Care Hospital in Eastern India. J Evol Med Dent Sci. 2013; 2(48): 9323-9328.

14. Sugandhi P, Prasanth D. Bacteriological Profile of Diabetic Foot Infections. Int J Innov Res Sci, Engin Tech (IJIRSET). 2014; 3(7): 14688-14692.

15. Madmoli M, Karami M, Madmoli Y. Some Effective Risk Factors on Diabetic Foot Ulcer: Study on 2643 Cases of Patients with Diabetes. J Res in Med Dent Sci. 2019; 7(3): 139-143.

16. Edo AE, Edo GO, Ezeani IU. Risk factors, ulcer grade and management outcome of diabetic foot ulcers in a Tropical Tertiary Care Hospital. Niger Med J. 2013; 54(1): 59-63.

17. Pal B, Gupta SA. Study on the relation of the severity of diabetic foot ulcers with the type of bacterial flora isolated from the wounds. Int Surg J. 2016; 3(1): 189-194.

18. İçer M, Durgun H. Factors Affecting Amputations in Patients with Diabetic Foot Ulcer Referring To the Emergency Units. Dicle Tip Dergisi/Dicle Med J. 2017; 44(1): 91-97. 
19. Paul S, Barai L, Jahan A, Haq J. Bacteriological Study of Diabetic Foot Infection in an Urban Tertiary Care Hospital of Dhaka City. Ibrahim Med Coll J. 2015; 3(2): 50-54.

20. Huang Y, Cao Y, Zou M, Luo X, Jiang Y, Xue Y, Gao F. A Comparison of Tissue versus Swab Culturing of Infected Diabetic Foot Wounds. Int J Endocrinol. 2016; DOI: http://dx.doi.org/10.1155/2016/8198714.

21. Yates C, May K, Hale T, Allard B, Rowlings N, Freeman A, Harrison J, McCann J, Wraight P. Wound Chronicity, Inpatient Care, and Chronic Kidney Disease Predispose to MRSA Infection in Diabetic Foot Ulcers. Diabetes Care. 2009; 32(10): 1907-1909.

22. Bello OO, Oyekanmi EO, Kelly BA, Mebude OO Bello TK. Antibiotic Susceptibility Profiles of Bacteria from Diabetic Foot Infections in Selected Teaching Hospitals in Southwestern Nigeria. Int Ann Sci. 2018; DOI: https://doi.org/10.21467/ias.4.1.1-13.

23. Ahmad W, Khan IA, Ghaffar S, Al-Swailmi FK, Khan I. Risk Factors For Diabetic Foot Ulcer. J Ayub Med Coll Abbottabad. 2013; 25: 1-2.

24. Wu M, Pan H, Leng W, Lei X, Chen L, Liang Z. Distribution of Microbes and Drug Susceptibility in Patients with Diabetic Foot Infections in Southwest China. J Diab Res. 2018; 1-9.

25. Saltoglu N, Ergonulb O, Tulekc N, Yemisena M, Kadanalid A, et al. Influence of multidrug resistant organisms on the outcome of diabetic foot infection. Int J Infect Dis. 2018; 70: 10-14.

26. Jain SK, Barman R. Bacteriological Profile of Diabetic Foot Ulcer with Special Reference to Drug-resistant Strains in a Tertiary Care Center in North-East India. Indian J Endocrinol Metab. 2017; 21(5): 688-694.

27. Hefni A, Al-Metwally R, Attia KM, El-ramah A, Shahin M, Al-Molla M, Abd Al-sattar L. Bacteriological study of diabetic foot infection in Egypt. J Arab Soci Med Res. 2013; 8: 26-32.

28. Benwan KA, Mulla AA, Rotimi VO. A study of the microbiology of diabetic foot infections in a teaching hospital in Kuwait. J Infect Public Health. 2012; 5(1): DOI: 10.1016/j.jiph.2011.07.004.

29. Dezfulian A, Salehian M, Amini V, Dabiri H, Rad M, Aslani M, Alebouyeh M, Fazel I, Zali M. Bacteriological Study of Diabetic Foot Infections in an Iranian Hospital. Iranian Red Crescent Med J. 2011; 15(8): 590-591.

30. Perim MC, Borges JD, Celeste SR, Orsolin ED, Mendes RR, Mendes GO, Ferreira RL, Carreiro SC, Pranchevicius MC. Aerobic bacterial profile and antibiotic resistance in patients with diabetic foot infections. Rev Soc Bras Med Trop. 2015; 48(5): 546-554.

31. Anand A, Biswal I, Soni R, Sinha A, Rynga D, Deb M. A clinico-microbiological study of diabetic foot ulcer patients to identify risk factors and their correlation with prognosis in tertiary care hospital in India. Int Surg J. 2016; 3(2): 669-673. 
32. Shanmugam P, Jeya M, Susan L. The Bacteriology of Diabetic Foot Ulcers, with a Special Reference to Multidrug Resistant Strains. J Clin Diag Res. 2013; 7(3): 441-445.

33. Anyim O, Okafor C, Young E, Anyim I, Nwatu C. Pattern and microbiological characteristics of diabetic foot ulcers in a Nigerian tertiary hospital. Afri Health Sci. 2019; 19(1): 1617-1627.

34. Misic AM, Gardner SE, Grice EA. The Wound Microbiome: Modern Approaches to Examining the Role of Microorganisms in Impaired Chronic Wound Healing. Adv Wound Care. 2014; 3(7): 502-510.

35. Wahab N, Samsudin I, Nordin S, Ahmad Z, Noor L, Devnani A. Clinical presentation and microorganisms sensitivity profile for diabetic foot ulcers: a pilot study. Med J Malaysia. 2015; 70(3): 182-187.

36. Nageen A. The Most Prevalent Organism in Diabetic Foot Ulcers and Its Drug Sensitivity and Resistance to Different Standard Antibiotics. J College of Physicians and Surgeons Pakistan. 2016; 26(4): 293-296.

37. Aamir A, Nasir A, Jadoon M, Mehmood K, Ali S. Diabetic Foot Infections and Their Management in A Tertiary Care Hospital. J Ayub Med Coll Abbottabad. 2011; 23(1): 58-62.

38. Pappu AK, Sinham A, Johnson A. Microbiological profile of diabetic foot ulcer. Calicut Med J. 2011; 9(3): 1-4.

39. Shashanka R, Rajanna B. Bacteriological Profile of Diabetic Foot Ulcers: A Clinical Study. IJSS Journal of Surgery. 2016; 2(3): 38-41.

40. Gillespie S, Hawkey P. Principles and Practice of Clinical Bacteriology. $2^{\text {nd }}$ ed. The Atrium, Southern Gate, Chichester, West Sussex PO19 8SQ, England. 2006.

41. Mendoza RA, Hsieh J, Galiano RD. The Impact of Biofilm Formation on Wound Healing. In: Wound Healing - Current Perspectives. 2019. p. 8-10.

42. Neidig A, Yeung A, Rosay T, Tettmann B, Strempel N, Rueger M, Lesouhaitier O, Overhage J. TypA is involved in virulence, antimicrobial resistance and biofilm formation in Pseudomonas aeruginosa. BMC Microbiology. 2013; 13(77): DOI: 10.1186/1471-2180-13-77.

43. Samant S, Victor S, Rai S, Aerobic bacterial Profile of Diabetic Foot Ulcers and their Antibiotic Sensitivity Pattern. Int J Curr Microbiol App Sci. 2018; 7(1): 1412-1418.

44. Ahmed M, Said M, Naira E, Fatania A, Emad E, Soma A. Infection in diabetic foot. Menoufia Med J. 2013; 26: 49-53.

45. Otta S, Debata N, Swain B. Bacteriological Profile of Diabetic Foot Ulcers. J Health Res. 2019; 6(1): 7-11.

46. Mottola C, Matias C, Mendes J, Melo-Cristino J, Tavares L, Cavaco-Silva P, Oliveira M. Susceptibility patterns of Staphylococcus aureus biofilms in diabetic foot infections. BMC Microbiology. 2016; 16(119): DOI: 10.1186/s12866-016-0737-0. 
47. Ogba OM, Olorode OA, Adie GP. Bacterial pathogens associated with wound infections in Calabar, Nigeria. J Med. 2014; 13(1): 26-33.

48. Ogba O, Nsan E, Eyam E. Aerobic bacteria associated with diabetic foot ulcers and their susceptibility pattern. Biomed Dermatol. 2019; 3(1): DOI: https://doi.org/10.1186/s41702-0190039-x.

49. Manisha J, Mitesh P, Nidhi S, Dhara M, Vegad M. Spectrum of Microbial Flora in Diabetic Foot Ulcer and its Antibiotic Sensitivity Pattern in Tertiary Care Hospital in Ahmedabad, Gujarat. Nation J Med Res. 2012; 2(3): 354-357.

50. Divya G, Pavithra B, Sathish B, Naveena R, Ashwini V, Sri Kiruthika K. Clinical and Microbiological Characteristics of Diabetic Foot Infections in Teaching Hospital at Kancheepuram District. Int J Phar Tech (IJPT). 2017; 9(1): 28488-28502.

51. Bengalorkar G, Kumar T. Culture and sensitivity pattern of micro-organism isolated from diabetic foot infections in a tertiary care hospital. Int J Cur Biomed Phar Res. 2011; 1(2): 3440.

52. Mathangi T, Prabhakaran P. Prevalence of Bacteria Isolated from Type 2 Diabetic Foot Ulcers and the Antibiotic Susceptibility Pattern. Int J Curr Microbiol App Sci. 2013; 2(10): 329-337.

53. Zubair M, Malik A, Ahmad J. Clinico-bacteriology and risk factors for the diabetic foot infection with multidrug resistant microorganisms in north India. Biology and Medicine. 2010; 2(4): 22-34.

54. Singh S, Banerjee G, Agarwal J, Kumar V, Usman K. Spectrum of microbiota in diabetic foot infections in a teaching hospital of Uttar Pradesh. Int J Med Sci Public Health. 2018; 7(9): 741747.

55. Manikandan C, Prabhakaran P. Clinical and bacteriological profile of diabetic foot infections in Pattukkottai area hospitals, Tamilnadu, India. Int J Curr Res Aca Rev. 2015; 3(4): 166-173.

56. Amaefule KE, Dahiru IL, Okpe IO, Aliyu S, Aruna AA. Clinico-microbial profile of diabetic foot infections in Zaria, North-West Nigeria. Sahel Med J. 2019; 22(1): 28-32.

57. Kumar A, Agrawal A, Kumar M, Sharma A, Kumari P. Aerobic Bacterial Profile of Diabetic foot and its Antibiogram in RIMS, Ranchi - a Tertiary Care Hospital. Int J Contemporary Med Res. 2017; 4(1): 251-253.

58. Mehta VJ, Kikani KM, Mehta SJ. Microbiological profile of diabetic foot ulcers and its antibiotic susceptibility pattern in a teaching hospital, Gujarat. Int J Basic Clin Pharmacol. 2014; 3(1): 92-95.

59. Ayub M, Rizwan H, Siddique S, Maryam U. Isolation of Pathogens Causing Sepsis, Pus and Infected Wounds from Critical Care Unit: A Retrospective Study. Ann Clin Lab Res. 2015; 3(4): 1-7. 
60. Xie X, Bao Y, Ni L, Liu D, Niu S, Lin H, Li H, Duan C, Yan L, Huang S, Luo Z. Bacterial Profile and Antibiotic Resistance in Patients with Diabetic Foot Ulcer in Guangzhou, Southern China: Focus on the Differences among Different Wagner's Grades, IDSA/IWGDF Grades, and Ulcer Types. Int J Endocrinol. 2017; DOI: https://doi.org/10.1155/2017/8694903.

61. Shnawa IM. The mucosal and systemic immune status for diabetic and non-diabetic Dentialvcolar infected patients. Baghdad Sci J. 2011; 8(1): 489-493.

62. AL-Allaff R, Al-Shahery M. Estimation of Phagocytic Activity in Diabetic Patients (Type 1, 2) in Mosul City. Rafidain Journal of Science. 2012; 23(4): 31-40.

63. Huang J, Xiao Y, Xu A, Zhou Z. Neutrophils in type 1 diabetes. J Diabetes Investig. 2016; 7(5): 652-663.

64. Ena J, Casañ R, Carratalá MJ, Leutscher E. Effect of a program to control perioperative blood glucose on the incidence of nosocomial infections in patients with diabetes: A pilot study. $\mathrm{J}$ Diab Mell. 2012; 2(2): 238-244.

65. Umadevi S, Kumar S, Joseph N, Easow J, Kandhakumari G, Srirangaraj S, Raj S, Stephen S. Microbiological study of diabetic foot infections. Indian J Med Speci. 2011; 2(1): 12-17. 
Figures

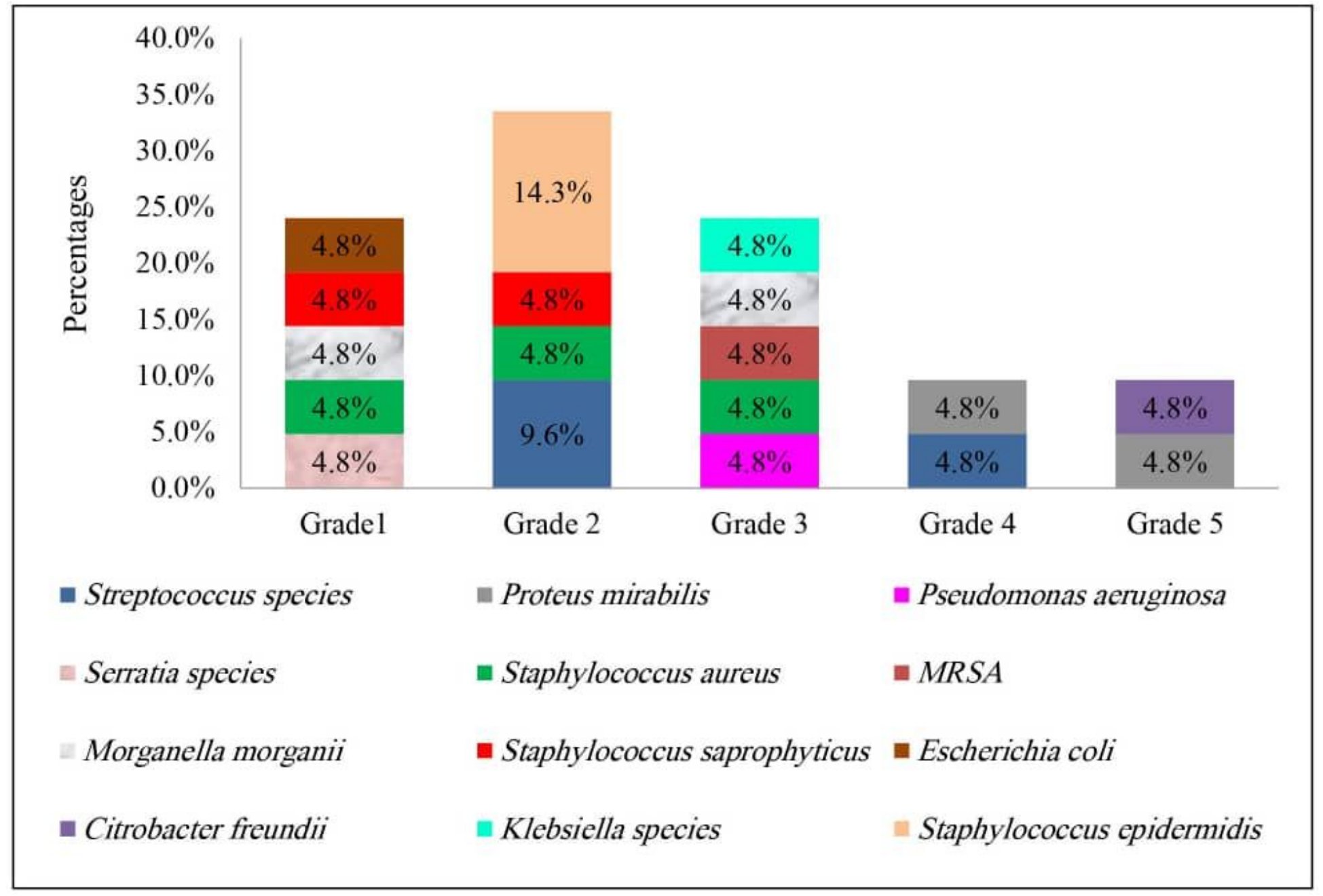

Figure 1

Bacterial species of DFU according to Wagner's ulcers grades classification 


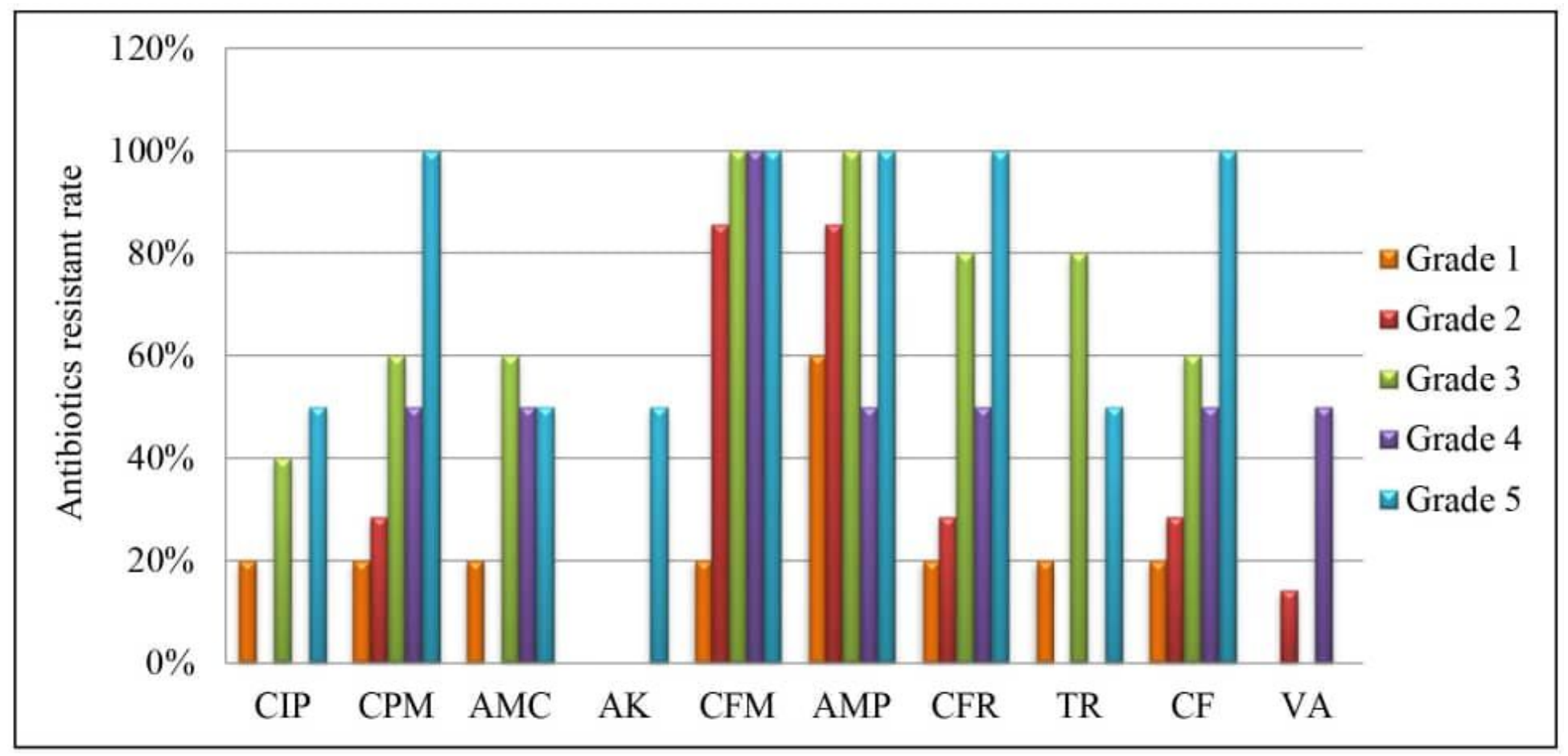

Figure 2

Antibiotics resistance patterns of bacterial isolated in different Wagner's grades

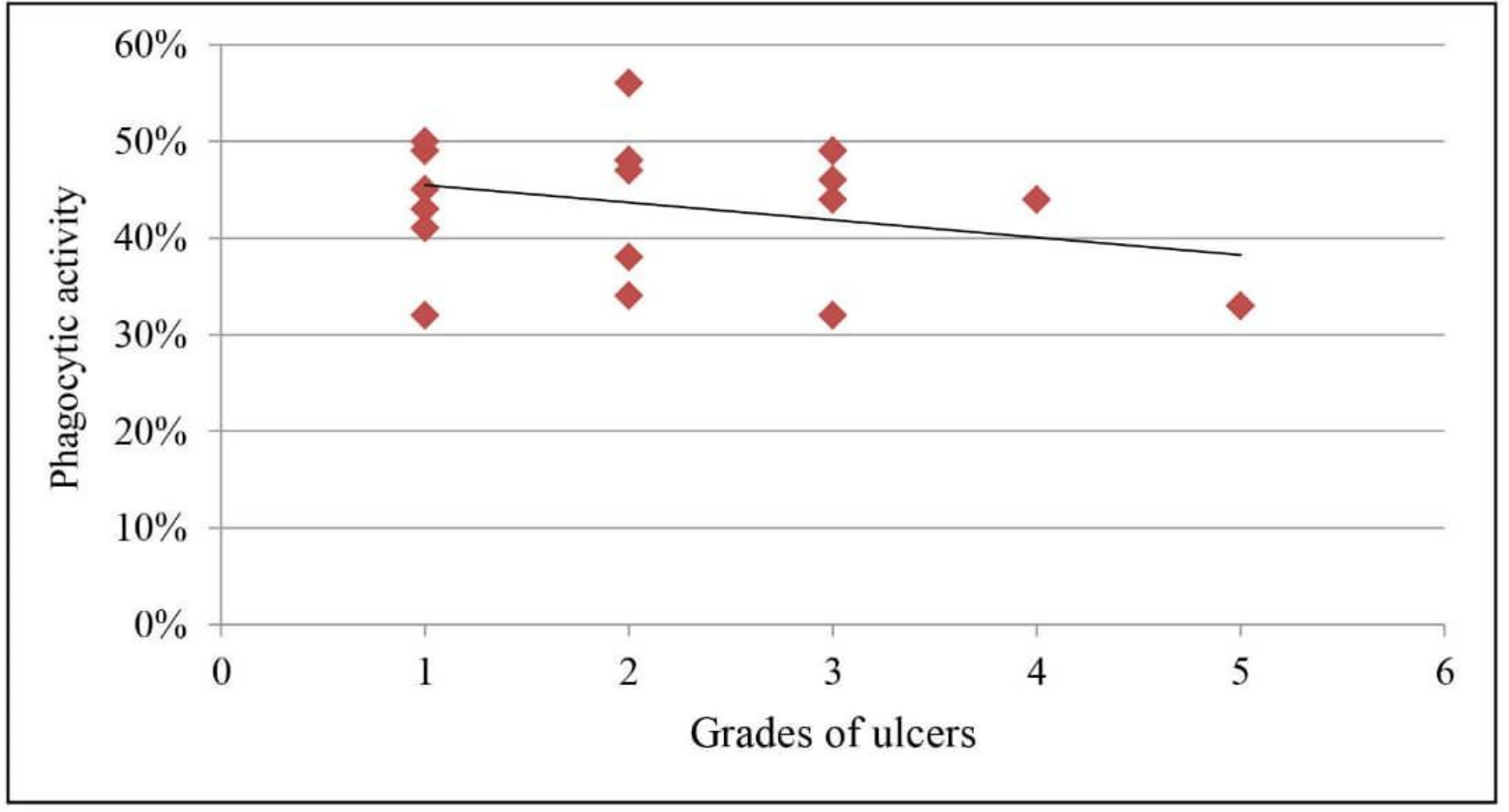

Figure 3

The correlation between phagocytic neutrophil cells activity and Wagner's grades of ulcers 